\title{
Local heroes - memory in action in the late renaissance garden
}

James M. BRAdBuRne*

\begin{abstract}
Hero of Alexandria was a prolific inventor who lived in the 1st century $C E$ and whose writings enjoyed a marked resurgence of popularity in Renaissance Europe. The Greek original of Hero's most influential text, the Mechanics, was lost early, and was only transmitted to the West in Arabic. The Greek text of his less important - and possibly unfinished - work on Pneumatics, however, found its way to Europe after the fall of Constantinople, where it had been preserved in what Will Noel calls 'the Ark for ancient literature'.

Texts often precede performance, but are equally often the consequence of a tradition of 'situated' or maker's knowledge. This paper looks at the ways in which knowledge became 'resituated' in the practice of Renaissance engineers, artists and garden architects through the rediscovery and diffusion of Hero's Pneumatics. It explores why Hero's Pneumatics enjoyed such new-found popularity in the 15th and 16th centuries, how Hero's texts were transmitted and interpreted, and to whom. The paper will argue that this revival in interest was due in part to the near-contemporary recovery of other classical texts, such as those by Archimedes, Vitruvius and Hermes Trismegistus. Finally, the paper will argue that the Renaissance memory of Hero's Pneumatics is best understood through built works rather than texts, and that these works played an important cultural and ideological role in the revival of neo-Platonism and neo-Pythagorean thought in post-Reformation Europe, losing their potency only with the end of the Thirty Years War.
\end{abstract}

Key words: Renaissance memory, Hero of Alexandria, Pneumatics, neo-Platonism, the Villa d'Este at Tivoli, the Villa Medici at Pratolino, the Hortus Palatinus at Heidelberg, museum, strategy of 'visible listening'.

Redaktionel kommentar:

Artiklen udspringer af et mundtligt oplag på seminaret "Erindring og glemsel", København, marts 2008 (se under rubrikken Konferencer og seminarer).
THE ORIGINAL HERO

Even though historians as late as the 19th century were uncertain of his dates, Neugebauer convincingly argued in 1938 that Hero of Alexandria lived about $62 \mathrm{CE}$, on the basis of 
astronomical evidence. Although Drachmann pleads his case, ${ }^{1}$ it seems that Hero was a 'Blist'engineer, overshadowed by Ctesibios and Philo (from whom he borrowed freely) and that Hero had the singular good fortune of having his works preserved, whereas those of his predecessors were lost, mentioned only by later writers such as Hero's contemporary Vitruvius. ${ }^{2}$ Of Hero's works, his Mechanics were far and away the most influential, followed by his Dioptra, Automatic Theatres and his Geometria. Drachmann argues that the Pneumatics and the Automata (often found together) were never finished, and consist of a series of notes on various 'toys', a position later reiterated by Boas ${ }^{3}$. Famously, these inventions included the eolipile, a supposed precursor of the steam engine, and various other devices that activated automata, opened curtains, caused statues to move or birds to sing. Most of them depended on an understanding of the ways in which air behaves when exposed to heat or cold, but unlike Philo, Hero also proposed devices that used sophisticated systems of pulleys, quite unparalleled until modern times. ${ }^{4}$ His pneumatic devices were based on a belief that air was a substance consisting of tiny particles, between which there was a vacuum. There is no continuous vacuum in nature, but as Hero's devices showed, air was susceptible to expansion and contraction, as the particles moved closer together or further apart. As Boas remarks 'Hero's Pneumatica is a treatise on natural magic, as later centuries called the unexplained properties of nature.' Toys or magic, Hero's inventions found a willing audience at the courts of the Renaissance, and his automata clearly responded to specific needs of the time and embodied specific understandings about the world and how it functioned. But how did Hero's writings sur- vive the fifteen centuries that lay between their writing and their reception in Renaissance Italy?

\section{INTO THE ARK}

Many ancient writers never survived the centuries after the Fall of Rome and the adoption of Christianity by the ruling classes. Either the texts did not make the jump from the medium of the papyrus roll on which they were originally written to the parchment codex, a process that took some three centuries to complete, or they were lost in the fires and disasters - natural and political - that beset the great libraries of the time, such as when the Archbishop of Alexandria sacked the Serapeum, the daughter library of the famous musaeum, in $391 \mathrm{CE}$. Alternatively, they were not copied because they had little to do with the roadmap for Christian salvation - they were not dangerous, they were merely irrelevant. In the course of the first eight centuries of the Common Era, countless classical texts were damaged, destroyed, lost or mislaid. There were only two havens left for classical learning - Constantinople and Baghdad. Writing about the preservation of the Archimedes palimpsest, Will Noel writes "Constantinople itself did the one thing it had to do for Archimedes, and for so many ancient authors; it survived. It was the only city of the ancient world of any consequence to survive unmolested into the Middle Ages. Constantinople served as the ark for ancient literature, and the Noah of the classics was the Emperor Theodosius. A hundred years before Isidore built his great church, Theodosius had already constructed the city's massive walls to weather the Dark Age storm." 6

The other escape route for ancient texts was 
76 through the Islamic world, and much of the legacy of Greek Antiquity first reached Europe in the Middle Ages through Arabic translations. In particular, the 'House of Wisdom' founded by Al Mansur in $762 \mathrm{CE}$ played a central role in preserving Greek science and astronomy. The House of Wisdom was originally charged with translating works from Persian, then from Syriac and only later Greek. Under the patronage of caliph al Mamun (813-833), the emphasis shifted from Persian to Greek science. At that time, the library was directed by the poet and astrologer Sahl Ibn Harun (d. 830) and other scholars associated with the library included some of the Islamic world's greatest astronomers and engineers: Mohammed ibn Musa al Khwarizmi (780850), the brothers Bana Musa and Yaqub ibn Ishaq al Kindi (801-873). Along with all the other libraries in Baghdad, the House of Wisdom was destroyed during the Mongol invasion of Baghdad in 1258 - it was said that the waters of the Tigris ran black for six months with ink from the enormous quantities of books flung into the river. Interestingly, although Hero is mentioned by Arab authors, many of his works did not appear to be widely read or used, and neither his name nor his works are mentioned by the historian $\mathrm{Al}$ Ya'qubi. Given the large number of spurious and pseudo-Heronic writings, however, his influence can be detected in the Arabic literature even when his name is not explicitly mentioned. For instance, it has long been noted that Al Khwarizmi's chapter on Geometry closely parallels Hero's, as do several other of his calculations. On the other hand, the three brothers Banu Musa appear not to have read Hero's Geometry, although Hero's books on Mechanics (which is only known through an Arabic translation), Pneumatics and especially his Automata, appear to have been read and used by both the Banu Musa and Al Jazari.?

Even though sacked ruthlessly by Christian forces during the Fourth Crusade in 1204, Constantinople remained a safe haven for numerous texts of Greek Antiquity, such those of as Hero, for a few centuries more. However, after the demise of the Comnenian dynasty at the close of the 12th century, the Byzantine Empire went into decline and the Byzantine emperors fled to nearby Nicaea, which became a camp for refugees from Constantinople. From this base, Constantinople was taken from its final Latin ruler, Baldwin II, by Byzantine forces under Michael VIII Paleologus in 1261 . By 1261, the population of the city may have fallen as low as 35,000, but Michael VIII succeeded in increasing the population to 70,000 people by the end of his reign. When the Ottoman Turks finally captured it in 1453, marking the end of the Byzantine Empire, the population was at 50,000 people - a quarter of its population at its height in the 12th century. With the arrival of the Turks, the door to Constantinople's treasures slammed shut. Happily, however, many had already found their way to Venice and the West.

\section{THE TROJAn HORSE}

How did the Greek text of Hero's Pneumatics find its way to Italy? In her landmark 1949 study of the transmission of Hero's writings, Marie Boas notes that fragments of his works had already circulated in manuscript form in the Middle Ages, and a partial translation of Hero's Mechanics is referred to by Henricus Aristippus. ${ }^{8}$ Nevertheless, all complete Greek manuscripts date to the 15 th century, brought to Italy from Constantinople. 
As Jonathan Harris writes, "The image of the Byzantine exiles as venerable scholars fleeing with their books under their arms represents both an exaggeration and an understatement. It exaggerates the part played by individual Byzantines in the revival of Greek learning in Italy, while ignoring the vast majority of the émigrés, who were involved in no scholarly activity whatsoever." Nevertheless, as Harris himself stresses, it is equally wrong to underestimate the importance of the scholars. "Certainly the Byzantine diplomat Chrysoloras played a key role when he was invited to teach Greek at Florence University in 1396. Chrysoloras only occupied this post between 1397 and 1400, but in that period had a tremendous effect. Among his pupils were some of the foremost figures of the revival of Greek studies in Renaissance Italy, including Guarino da Verona (1374-1460) and Palla Strozzi (1372-1462).

Chrysoloras was not the only one to receive such a welcome. When George Gemistos Plethon attended the Council of Florence in 1439, his lectures on the differences between the work of Plato and Aristotle were eagerly received and prompted the later comment of Marsilio Ficino (1433-99) that Plethon had brought the spirit of Plato from the Byzantine Empire to Italy." 10 Next to Chrysoloras, the towering figure in the transmission of Greek learning to Renaissance Italy was Cardinal Bessarion.

Bessarion's importance as a defender of Plato in the early Renaissance cannot be underestimated. As Harris writes, "During the 1450 s and 1460s, a debate raged in Rome as to whether it was legitimate for Christians to read Plato, and the community of Greek scholars was at the centre of the controversy. The household of Cardinal Bessarion, close to the church of the Holy Apostles, became a meeting place for Greek and Italian scholars, often known as the 'Academy', where this issue could be discussed. All the aspirations of Bessarion were driven by three ideas: the union of the Oriental Church with the Latin, the rescue of Greek lands from Muslim domination, and the virtues of classic literature and philosophy, especially the Greek. Over the years he had assembled an extensive library of Greek codices, many of them brought with him from Constantinople, others he had copied at his own expense. After he became Patriarch of Constantinople, he gave his treasures to the Republic of Venice where they formed the nucleus of the famous Biblioteca Marciana. Of all of Bessarion's legacies, this was perhaps the most far-reaching. In 1469, he presented his immense library of over 900 volumes, many of them copied by the scribes, to the church of St. Mark in Venice. Bessarion chose Venice partly because he considered it the most politically stable and secure of the Italian city states, and partly because it had offered a refuge for so many of his fellow Greeks. With the advent of printing, in the 1490 s the Italian printer Aldus Manutius established a Greek press in Venice. The choice of location was no doubt dictated by the availability of Greek texts in the library of St. Mark's, for Manutius based his editions on these books. It was with the help of émigré Greeks such as Demetrius Doukas and Mark Mousouros that Manutius produced printed editions of nearly all the works of the major Greek authors of Antiquity before 1515, thus ensuring their survival for posterity. ${ }^{11}$

\section{THE HEROIC AGE}

Despite having arrived in manuscript with 
Bessarion - the Pneumatica was certainly present in the earliest inventory of his library in $1468^{12}$ - Hero had to wait over a century before being translated into Latin and the vernacular. The first fragments of Hero appeared in Latin as a paraphrase in Giorgio Valla's De expetendis et fugiendis rebus, published in Venice in $1501^{13}$. The first Latin edition was published by Federico Commandino (1506-1575) in Urbino in $1575,{ }^{14}$ as part of a broader project to make Greek learning available in the lingua franca (he also published editions of Archimedes, Aristarchus, Euclid, Ptolemy and Pappus, as well as De superficierum divisionibus by Machometus Bagdedinus at the request of John Dee in 1570). Urbino and the court of Duke Federigo da Montefetro had been a flourishing centre for humanist studies since the 1460 s and Montefeltro's library was among the most renowned in Italy. Despite the gift of donation to Venice in 1468, and perhaps to protect them from being appropriated, Bessarion confided a large number of his Greek manuscripts to Federigo in 1471, and they were only finally removed to the Biblioteca Marciana in 1474. According to the 1474 inventory, Hero's works were among the books sent from Urbino. ${ }^{15}$ Given the interest in Greek texts and the availability of willing scribes in Urbino, it seems likely that Hero's text was transcribed before it left for Venice, and it seems likely a Greek manuscript copy was in the Biblioteca Urbinate when it was removed to Rome in $1627^{16}$ to form - along with the great Biblioteca Palatina, the spoils from the sacking of Heidelberg by Spinola's troops in 1621 - the nucleus of the great Biblioteca Vaticana. It thus seems likely that Commandino and Baldi both would have consulted the Greek manuscript copy in the Duke of Urbino's library. ${ }^{17}$
With Commandino's Latin edition (which was subsequently reprinted in Paris in 1583 and again in Amsterdam in 1680, in a lavish illustrated edition ${ }^{18}$ ) the explosion of interest in Hero's Pneumatics begins in earnest. ${ }^{19}$ The first printed editions of Hero's Pneumatica in vernacular Italian appeared in 1589, the illustrated edition by Aleotti ${ }^{20}$ published in Ferrara, and the translation by Commandino's collaborator in Urbino, Bernardino Baldi ${ }^{21}$ (Baldi's work was re-published in 1601). The vernacular editions were generally not translated directly from the Greek, but instead from Commandino's Latin edition. Another Latin edition, by Alessandro Giorgi - who was also active at the court in Urbino and claimed Commandino as a colleague - appeared in 1592.22 Even after the first printed editions, Hero's works were still copied and circulated in manuscript form, notably by Bernardo Davanzati and Oreste Vannoccio Biringuccio in 1582 , both prepared for Buontalenti. Hero's works also found their way into the literature on natural magic, such as Giambattista Della Porta's Pneumaticorum Libri tres, which was based almost entirely on Hero, and the numerous other 'Books of Secrets' that flourished in the second half of the 16th century. ${ }^{23}$

By the end of the16th century, Europe abounded with literature on mechanical devices such as pumps, mills and fountains, such as Ramelli's (1531-1600) Le Diverse et Artificiose Macchine ${ }^{24}$ Jacobo Strada's (1515-1588) Kunstliche Abriss allerhand Wasser-Wind-Rossund Handt Müblen, etc. ${ }^{25}$ Jacques Besson's Theatrum instrumentorum et machinarum ${ }^{26}$ and Giovanni Battista Della Porta's Magiae Naturalis libri viginti ${ }^{27}$ - all informed at least in part by the rediscovery of Hero of Alexandria's writings. This should not suggest that Hero had become a household word - at least 
not yet. As Alexander Marr notes in his authoritative updating of Boas's survey, we must be more cautious than Boas herself was in assuming that just because a printed text was available, that it was widely read. 'As one might expect, the library lists of those authors writing on automata in the period include copies of these books [the Corpus Heronicum]. John Dee owned Commandino's Latin translation of the Pneumatica, whilst Baldi owned this edition and Giorgi's 1592 Italian translation. [...] Yet the surviving evidence prompts a rather more conservative estimate of the geographical extent of the books' circulation than has previously been supposed. ${ }^{28}$ Notwithstanding this understandable scholarly reserve, it is clear that Hero's works - and in particular the Pneumatica and the Automata - enjoyed an unprecedented popularity in the last quarter of the 16th century, a popularity that was only to grow in the first decades of the 17 th century.

\section{WHO NEEDS NEW HEROES?}

But why now? What accounts for the renewed interest in Hero's writings in the late Renaissance, specifically after 1500 ? To understand the explosion of interest in Hero and his pneumatic wonders, we have to return to the fertile years in which the first Greek texts arrived in Italy, and made their way to the Medici court in Florence in the mid-fifteenth century. The key figure in the translation of Greek texts into Latin was Marsilio Ficino. When Cosimo de Medici decided to re-establish Plato's Academy in Florence, his choice to head it was Ficino, who made an authoritative translation of Plato in 1484, as well translating a collection of Hellenistic Greek documents of the Corpus Hermeticum and the writings of many of other Neoplatonists such as Porphy79 ry, Iamblichus and Plotinus. Following the lead of Gemistos Plethon, Ficino tried to conflate Christianity and Platonism, while his interest in astrology and astral influences described in the Hermetic texts brought him to the attention of a suspicious and sceptical Church. Most importantly, the Ficinian enterprise was one of recovering texts - seen to be the door to ancient knowledge, and the key to recreating the golden age of Classical Antiquity. Inheritor of a long tradition of textual exegis, Ficino was reluctant to see the texts he translated as operative; aimed at doing rather than merely understanding. For Ficino, texts were just that - texts. To his successors, however, texts were more than just texts, they were instructions - recipes for intervening in the real world.

Very broadly put, the climate of Renaissance humanism fostered at the Medici court nourished the belief that Man could operate not only in the physical realms, but in the intellectual and divine realms as well, by means of the correspondences operating at different levels of the putative angelic hierarchy. ${ }^{29}$ According to Agrippa and Reuchlin, for instance, the powers of the angels could be invoked if the adept could discover their Hebrew names by means of Cabalistic formulae and numerological manipulations. ${ }^{30}$ As promoted timidly by Ficino, and more aggressively by Pico della Mirandola, Renaissance neo-Platonism, conflated with the so-called prisca theologia of Hermes Trismegistus, provided the philosophical underpinning to the pursuit of most natural philosophy well into the mid17 th century. ${ }^{31}$ In this hybrid, text, image, objects and number provided privileged insights into the natural world, and into the world of the spirit, as defined by the humanist doctrine 
of the microcosm and the macrocosm, and by the Hermetic three worlds of the terrestrial (man), celestial (astral influences mediated by angels and demons) and super-celestial (the divine).

According to this view, the world was God's book, and his answers were written in it for all to seek. God's immanence in the world meant, among other things, that all relations were real relations, that mathematical truth, the behaviour of the stars and planets, and the characteristics of natural phenomena were all presentations of God's mind in the world. There was no question of a proportion adequately representing beauty, it was beauty. In the same way, neither did a talisman need to represent an abstract quality, it was the quality. It must be emphasised that in the Renaissance there are no gaps between thought and signs and between signs and reality - as there was later to be in Descartes' mathematicised and mechanistic universe. To the Renaissance thinker, relations between objects, numbers, and images were real relations, and they did not stand for relations in any arbitrary way. Equally, words and signs were knowledge, they did not merely stand for knowledge. This approach thereby avoids one of the key problems of modern epistemology, that of the adequacy of relation between ideas and things, words and ideas. The key expression of this view is the so-called Corpus Hermeticum, a varied body of writings which include the $P i$ mander, the Asclepius, a well as the highly magical Picatrix, originally attributed to an Egyptian Magus contemporary with Moses, and later shown to have been written in the early centuries of the Common Era. The key text in this approach to the world can be found in the Asclepius, the only book of the Corpus Hermeticum already available in Latin in the Middle Ages (and roundly condemned by St Augustine ${ }^{32}$ ), newly translated from the Greek by Ficino in 1463 . In a celebrated passage, Trismegistus tells Asclepius that man can author gods, in the form of statues in which were animated by drawing down celestial influences using talismans and images. Just prior to this passage, Trismegistus describes the seven spheres who have Fortune or Destiny as their ruler, and states that 'Air is the instrument or organ of all these gods'.$^{33}$ Over a century later, in the introduction to his 1592 translation of Hero's Pneumatica (De spiritualis), Alessandro Giorgi situates Hero in the Platonic discourse: 'spirituali comes from the spirit, and Hero intends by this use of spirit, the affected air, which was also the opinion of Hippocrates, as is seen in the Book of the Spirit of Plato in his Timaeus'. ${ }^{34}$

It is important to stress that up till now, Hero has been translated as a text, and represented many things: the recovery of ancient wisdom, an instruction manual for making machines, a key to magical knowledge. But first and foremost it had been translated as part of a textual tradition of copying and recopying, of reading and glossing and requoting. Even after decades of scholarly revision of the more exaggerated and extravagant claims of historians of the Renaissance such as Yates, Gombrich, and Rossi, ${ }^{35}$ it can still be argued that an important sub-text of the late Renaissance court was the belief - or at least the awareness - of Christian Cabalist hermetic neoPlatonism, in which one possible task of the natural philosopher was to establish correspondences between the ideal and real worlds in order to better understand the workings of nature, which was God's book, on the one hand, and to control nature by means of these correspondences, on the other. According to 
this world view, by creating the correct correspondences between objects, images, texts and the greater worlds of the angels, the natural philosopher would be able to participate in divine or quasi-divine powers. In fact, Yates and others argue that the position taken on the 'god-making' section of the Asclepius situates the writer precisely in the Christian Hermetic landscape of Renaissance thought.

It is precisely this intellectual environment of Christian Hermeticism built on Ficino's translation of the Corpus Hermeticum - contemporary with Bessarion's stay in Italy with the Corpus Heronicum - that fuelled an interest in automata and other 'animated statues'. Air was still the instrument of the gods, and these statues were still considered natural magic - as practitioners found to their dismay ${ }^{36}$ but instead of being powered by astral influences and inhabited by demons, they were worked by bellows, kettles and siphons. Along with Grafton, I believe that the enormous interest in Hero's Pneumatica was one of the consequences of an intellectual environment in which theological, philosophical and protoscientific speculation found a practical outlet for expression among the architects, engineers, artists and alchemists that peopled the courts of sixteenth century Europe. Did the engineers who read the texts - or tried to use them - actually believe they were calling down astral powers? Like their colleagues the alchemists and other natural philosophers, the answer is probably that failing a full understanding of the factors involved, they were prepared to make allowances for the putative effects of astral influences, ${ }^{37}$ while at the same time it is unlikely that few makers of automata - even failing a working notion of 'air' - believed that their movements relied on anything but the workings of kettles, lead tubing and greased leather. In this way, it is likely that the beliefs - and the practices - of the readers of texts and the makers of wonders diverges significantly.

\section{FROM HEROIC WORDS TO HEROIC DEEDS}

As with Vitruvius, Hero is remembered not only - or perhaps best - by his writings, but in the uses to which he was put, notably in the Italian Renaissance garden. Courts thirsty for innovation vied with one another in creating spectacles, pageants and gardens filled with hydraulic and mechanical wonders. Three gardens typify this translation of Hero's Pneumatica into real, tangible built objects: the Villa d'Este at Tivoli, the Villa Medici at Pratolino and the Hortus Palatinus at Heidelberg.

Villa D'Este. The Villa d'Este was arguably the first important Italian garden to use a wide variety of hydraulic and pneumatic techniques. It was commissioned by Cardinal Ippolito II d'Este (1509-1572), son of Alfonso I d'Este and Lucrezia Borgia and grandson of Pope Alexander VI and completed in 1605 by his heirs. Ippolito II had the villa reconstructed to plans of Pirro Ligorio under the direction of the Ferrarese architect-engineer Alberto Galvani, court architect of the Este family. Pirro Ligorio, who was responsible for the iconographic programs worked out in the villa's frescos, was also commissioned to lay out the gardens for the villa, with the assistance of Tomaso Chiruchi of Bologna, one of the most skilled hydraulic engineers of the sixteenth century. Ligorio, Vignola and Chiruchi also worked on the fountains at Villa Lante at Bagnaia near Viterbo, and Ligorio was later responsible for the famous Mannerist garden at Bomarzo. The garden is laid out on a central axis and includes some five hundred jets in 
82 fountains, pools and water troughs, supplied by the nearby river Aniene, which is partly diverted through the town, and by the Rivellese spring, which supplies a cistern under the villa's courtyard. The garden's iconography is drawn largely from Ovid's the source of much Renaissance imagery. The villa's uppermost terrace ends in a balcony with a sweeping view over the plain below. Double stairs flanking the axis lead to the next garden terrace, with the Grotto of Diana, richly decorated with frescoes and pebble mosaic to one side and the central Fontana del Bicchierone attributed to Bernini, where water issues from a seemingly natural rock into a scrolling shell-like cup. To descend to the next level, the visitor is required to take stairs at either end - the elaborate fountain complex called the Rometta is at the far left - to view the full length of the Hundred Fountains on the next level, where the water jets fill the long rustic trough. A visitor may then walk behind the water through the arcade of the concave nymphaeum, which is peopled by marble nymphs by Giambattista Della Porta, whose writings on pneumatics were derived almost entirely from Hero. Above the nymphaeum, the sculpture of Pegasus recalls to the visitor the fountain of Hippocrene on Parnassus, haunt of the Muses, a theme that recurs in many of the Este-derived gardens. This terrace is linked to the next by the central Fountain of the Dragons, dominating the central perspective of the gardens, erected for a visit in 1572 of Pope Gregory XIII, whose coat -of arms features a dragon. Central stairs lead down a wooded slope to three rectangular fishponds set on the cross-axis at the lowest point of the gardens, terminated at the right by the water organ ${ }^{38}$ and Fountain of Neptune.

The fascination with water organs may also be due in part to the influence of Renaissance neo-Pythagoreanism and neo-Platonism, as Renaissance thinkers of all kinds were involved in the recovery of the Orphic hymns; the music by which Orpheus was said to have quieted wild beasts. Orpheus was believed to be one of the chief poets and musicians of Antiquity, and the inventor of the lyre. With his music and singing, he could charm wild beasts, coax the trees and rocks into dance and even divert the course of rivers. As one of the pioneers of civilization, he is said to have taught humanity the arts of medicine, agriculture and writing. He was also closely connected with the magical arts, especially astrology, and is said to have founded or several important cults, such as those of Apollo and Dionysius. In addition to the well-known story of Orpheus and Eurydice (Metamorphoses XI), Ovid also recounts that the Maenads, angry for having been spurned in favour of 'tender boys', first threw sticks and stones at him as he played, but his music was so beautiful even the rocks and branches refused to hit him. Enraged, the Maenads tore him to pieces during the frenzy of their Bacchic orgies. A number of Greek religious poems were attributed to Orpheus, but of this vast literature, only two examples survive whole: a set of hymns composed at some point in the second or third century CE, and an Orphic Argonautica composed somewhere between the fourth and sixth centuries CE. Clearly Orpheus's ability to call down astral influences resonated with the Hermetic doctrines, and throughout Europe poets, musicians and engineers, notably the Pléiade, were inspired by the possibility of recovering pristine ancient rhythms in poetry and music. For some of the members of the Pléiade, such as Pontus de Tyard, the act of the poetry itself was seen as a form of divine 
inspiration, a possession by the Muses similar to romantic passion, prophetic fervour or alcoholic delirium. ${ }^{39}$

It is not clear to what extent Ligorio had read Hero, but he had certainly been in Urbino in the early 1540 s, where he was responsible for the decoration of the Loggia of the Palazzo Ducale, and could well have had access to Hero in manuscript. At Villa d'Este, he was assisted by a Frenchman, Claude Venard, who was an experienced manufacturer of hydraulic organs. Organs figured not only in the Corpus Heronicum, but notably also in Vitruvius, who was widely translated by the mid-sixteenth century. Michel de Montaigne's Journal de voyage en Italie (1580-81) contains one of the best contemporary accounts of the Villa d'Este's use of water organs ${ }^{40}$ :

The music of the [water] organ, which is real music and a natural organ, though always playing the same thing, is effected by means of the water, which falls with great violence into a round arched cave and agitates the air that is in there and forces it, in order to get out, to go through the pipes of the organ and supply it with wind. Another stream of water, driving a wheel with certain teeth on it, causes the organ keyboard to be struck in a certain order; so you hear an imitation of the sound of trumpets. ${ }^{41}$

Evidence for the Villa d'Este's team having been familiar with at least some of Hero's writings would seem to come from a passage in which Montaigne describes almost verbatim an example used by Hero himself in his Pneumatica $^{42}$ :

In another place you hear the song of birds, which are little bronze flutes that you see at regals; they give a sound like those little earthenware pots full of water that little children blow into by the spout, this by an artifice like that of the organ; and then by other

springs they set in motion an owl, which, appearing at the top of the rock, makes this harmony cease instantly, for the birds are frightened by his presence; and then he leaves the place to them again.

Pratolino. The Heronic villa par excellence was the Villa Medicea at Pratolino, built by the solitary Francesco I de Medici in part to please his Venetian mistress, the celebrated Bianca Cappello, to designs of the polymath Bernardo Buontalenti (1536-1608) from 1569 to 1581 , although it was used to provide the setting for Francesco's wedding to Bianca Cappello in 1579.

The garden was laid out along a perfectly straight axis passing through the centre of the villa, which stood midway. Down the central descent, the visitor still walks under a cooling arch of fountain jets, without getting wet. Michel de Montaigne, one of the earliest visitors to leave a description of Pratolino, saw it in 1581, and considered it to have been built to rival the Villa d'Este. A long description was published by a Florentine, Francesco de'Vieri, in 1586 describing the garden's myriad mechanical wonders ${ }^{43}$ " .... where the statues there turn about, play music, jet streams of water, are so many and such stupendous artworks in hidden places, that one who saw them all together would be in ecstasies over them." All that remains of the complicated iconography of the garden is the huge lowering statue of Appennino by the Flemish sculptor Giambologna (1529-1608) that seems to emerge from the niche that once surrounded him. In its heyday, multiple grottoes with water-driven automata, a water organ and hidden giochi dell'acqua drenched visitors when the fontanieri opened secret spigots, made a striking contrast with imitations of rugged Nature. Pratol- 
84 ino was famous for its musical automata, which 'made music and noises of every kind' ${ }^{44}$ An English visitor to the garden wrote in 1594 you can see the Cave of Aeolus, another of Parnassus, where with the turning of a cocke, a paire of organs doth make musicke and there is a head which together with his eyes is moved to and fro by unseen water. ${ }^{25}$ Here Evelyn would take delight in Pan, 'the Water making a melodious sound through his pipe,' and the soon-to-be-ubiquitous Mount Parnassus where the Muses played on hydraulic organs - 'going further can be found a Mount Parnassus [...] along with the nine Muses and an organ, which makes sweet sounds by means of water. Entering the Mount can be found the machines that make the sounds [...] at the top can be seen the winged Pegasus, below it a spring feeding a fountain'. ${ }^{46}$

The gardens at Pratolino were considered the best of their kind by contemporaries, who reported 'the works and artifices are marvels and a wonder of the first order, for their cause is not discovered right away, and because they are made with such virtue as is beyond common use'. ${ }^{47}$ In the verses composed for the wedding of Francesco with Bianca Cappello, Rafaello Gualterotti enthused 'In your beautiful garden is an earthly Paradise, perhaps even a heavenly one [...] here Art and Nature together grant every of their graces [...] a make each hour of the beautiful day more splendid still with new marvels'. ${ }^{48}$ That Pratolino was shaped by a close reading of Hero's Pneumati$c a$ is highly probable. ${ }^{49}$ Commandino's Latin edition was in circulation, and Buontalenti had friends - if he needed them - who could explain the Latin text to him. It was clearly important to Buontalenti to have an Italian translation of Hero to hand: Bernardo Davanzati dedicated his Italian translation of the preface Hero to Buontalenti, ${ }^{50}$ and Birunguccio translated the entire text for him into Italian in 1582 - albeit the year after Pratolino had been completed. ${ }^{51}$

Pratolino exercised an enormous influence as travellers returned from their Italian tours and engineers began to transplant the wonders they had seen into fresh soil. Tommaso Francini (1571-1651) and his younger brother Alessandro were responsible for carrying the Heronic marvels of Pratolino north at the request of Maria de Medici, married to Henri IV of France. Their first project, begun in 1598, was to provide fountains, grottoes, waterworks and water-driven automata for the series of garden terraces at Saint-Germain-enLaye. The main feature there was a great fountain and various elaborate automata. The upper grottoes opened from a Doric gallery and featured a dragon, a now-familiar water organ and a Neptune; on the next level, the Grotto of Hercules was flanked by two further grottoes; that on one side was devoted to Perseus and Andromeda, in which the delicately counterbalanced hero was made to descend from the ceiling by the hidden weight of water and slay a dragon that arose from the basin - a direct quotation from Hero $^{52}-$ and on the other a Grotto of Orpheus. The only trace of these features that remained after the court moved permanently to Fontainebleau are some engravings by Abraham Bosse, said to derive from Francini drawings. Ever-fascinated by gardens, when Evelyn visited Saint Germain, he was impressed by "Orpheus, with his musique, \& the Animals which daunce after his harpe [...] Neptune sounding with his Trumpet [...] and birds chirping and the many other devices". ${ }^{53}$

Hortus Palatinus. Perhaps the apogee of Hero's memory can be found not in his wri- 
tings, but in the famous garden of Frederic V, the Hortus Palatinus, designed by Salomon De Caus. Salomon De Caus was born to a Huguenot family in Dieppe in 1573, and died in Paris in 1626. As a young man, De Caus had been in Italy between 1595 and 1598, and by his own account visited Pratolino. From 1601 (and probably earlier) until 1608, he was employed by the Habsburg Archdukes Albrecht and Isabella in Brussels. ${ }^{54}$ De Caus was appointed Chief Engineer in 1605, under the supervision of Wencel Cobergher, responsible for water-raising devices and other waterworks, as well as grottoes and fountains. He is said to have left the employ of the Archdukes in a fit of spleen after the Duke of Condé left his ornate grotto 'rompu et gasté' in $1607^{55}$ and set his sights on the court of James VI/I in London, where some of his Protestant relatives had already settled. If his preface to La perspective avec la raison des ombres et mirroirs ${ }^{56}$ is to be believed, De Caus must have had good contacts at the English court of James VI/I, as he was already tutoring the young Prince Henry in drawing in 1608, and De Caus'first book is later dedicated to him. In 1609, he was employed by Anne of Denmark to create a Pratolino-like fountain and Mount Parnassus at Somerset House, whose decoration prefigures the Tethys Festival, on which the Dutch inventor Cornelis Drebbel is said to have worked. ${ }^{57}$ We know that Anne, too, was no neutral observer, but had a keen interest in novelties - especially those that might bear on her much-enjoyed court entertainments - and by one account 'the Earl [Lord Percy, 9th Earl of Northumberland, imprisoned in the Tower along with Raleigh 1605-1621 ] got seaverall Learned persons to live and Converse with him' among them were 'Mr. Heriot [Thomas Harriot 1560-1621], who presented Queene
Anne with a viol of water which ebbed and flowed at the same time as the Thames'.$^{58}$ clearly based on Drebbel's remarkable perpetuum mobile presented to the court in 1607.59

By whatever agency, by 1611 De Caus was appointed Architect to the court of Henry Prince of Wales, ${ }^{60}$ where Drebbel and Inigo Jones were also active, although he was forced to cede his place to the sharp-elbowed Florentine Constantine de Servi soon afterwards. This was a fertile environment, with myriad possibilities for encounters, exchanges and the cross-fertilisation of ideas. Unfortunately, the untimely death of Prince Henry in November 1612 shook the foundations of radical Protestant Europe, and De Caus found himself without a patron. Soon afterwards, however, he set out for Heidelberg in the train of Frederic $\mathrm{V}$, the Elector Palatine and his young bride, Henry's sister Elizabeth. Employed as Frederic's architect, Salomon de Caus was to create at Heidelberg the most complete example of the Renaissance garden north of the Alps, the Hortus Palatinus.

The great gardens of Heidelberg were laid out in the grounds of the castle of the Counts Palatine in Heidelberg, which overlooked a strategic crossing on the River Neckar, a tributary of the Rhine. The Prince-Elector (Kurfürst) of the Electoral Palatinate was one of the few nobles with the privilege of electing the ruler of the Holy Roman Empire, in the 16th century firmly in the hands of the Austrian Habsburgs. The Palatinate was strictly Calvinist, and in addition to its Electoral privileges, its strategic position along the main northsouth route to the Low Countries, and particularly the Spanish Netherlands, gave it an importance far greater than its small size would suggest. In 1613, the young 'Palsgrave' Frederic V married Elizabeth, the daughter of 
James I/VI, and by so doing became the voice of the militant Protestants in Europe who had opposed themselves to Habsburg hegemony. On the one hand, Frederic V inherited the mantle of Elizabeth's brother Prince Henry, ${ }^{61}$ who had been seen by many as the champion of an aggressive anti-Habsburg foreign policy, ${ }^{62}$ and on the other, he was seen as the last hope for a Hermetic Christian Renaissance. ${ }^{63}$ Frederic unwisely accepted the crown of Bohemia in 1619, and left Heidelberg with his wife to set up court in Prague from whence they were rudely ejected by Habsburg troops after the Battle of White Mountain in 1620 , after only one brief winter's reign as masters of the Hradcany and its Rudolphine wonders.

It is one of the characteristics of history that historical actors are unaware of what will happen next, ${ }^{64}$ so it was with considerable optimism that De Caus began work on the gardens in Heidelberg in 1613, seeing them as the culmination of his frustrated attempts to create the ideal Renaissance garden for English patrons in England. ${ }^{65}$ In order to create the Hortus Palatinus, De Caus had to overcome several significant technical challenges, not least of which was the creation of four extensive terraces in the shadow of the ridge from which the castle overlooked the Neckar and the town of Heidelberg. The garden itself is laid out along two major axes, and comprises a series of parterres and broderies that, according to Richard Patterson, form part of a neoPlatonic narrative of ascent through the harmonic mysteries of the microscosm and macrocosm. ${ }^{66}$ More recently, a sober analysis by Luke Morgan challenges the Yates-inspired Hermetic reading of the garden, and argues that De Caus was merely using the conventional topoi and themes that were the common- place of the late sixteenth and early seventeenth centuries. ${ }^{67}$ De Caus himself was explicit in acknowledging his debts, both to ancient sources such as Hero and Vitruvius, and to modern influences such as Tyard and the Pléiade. $^{68}$

De Caus's borrowings were also clear in the built fabric of the garden itself. In the main water parterre the sculptural figures, such as a woman squeezing water from her hair, are direct quotes from Giambologna and Nicolo Trobolo's work now at the Villa Petraia and the laundress is a quote from Giambologna's figure at Pratolino, a theme he used again at the Medici gardens at Castello. The garden's grottoes are inhabited by the now familiar automata drawn from Hero and numerous water organs, in which De Caus was a specialist. The iconography is unremarkably Ovidian, and references abound to the heraldic lion of Frederic V. The entire garden, of course, is also a paean to water, and water-driven automata based on Hero are present throughout the garden. The other major theme of the garden was love, as the garden was a gift to the Elector's bride, Elizabeth Stuart, who had left behind her the world of the English court, where her mother Anne of Denmark had De Caus build her a Parnassus of her own, based on the Parnassus at Tivoli and Pratolino at Somerset House. ${ }^{69}$ In this respect, the garden functioned as the stage for an elaborate masque, in which the Elector and Electress played the principal roles - also not unsurprising for a couple known to love English theatre, and for whose nuptials were created masques by Thomas Campion with stage designs by Inigo Jones, as well as plays by Shakespeare, notably the Tempest. ${ }^{70}$

In a very real sense, Patterson and Morgan are both correct, despite their highly divergent 
readings, but their analyses highlight the importance of asking: for whom did the gardens mean what? Patterson's reading of the garden as a Hermetic universe in miniature was probably shared by many contemporary visitors to the gardens, notably its noble patrons, well aware of the intellectual currents of the time and the hopes placed in Frederic V. On the other hand, Morgan clearly captures the likely attitude of De Caus, whose understanding was one of a 'writer' of gardens, not a reader. Morgan convincingly argues that with the exception of his affinity for the harmonic theories of the Pléiade and a detailed awareness of Renaissance iconography and the classical sources now available, combined with a personal experience of Pratolino and perhaps other Italian gardens, De Caus held a more sober and even sceptical position when it came to the super-celestial significance of his carefully laid-out knots, parterres and labyrinths. As an engineer, he saw his greatest triumph as the Orangerie, in which tropical fruit could grace the tables of the Palsgrave even in the wintera rare treat for the soon-to-be Winter King.

\section{THE DEFENESTRATION OF HERO}

The great gardens of the Hortus Palatinus were never to be completed. With Frederic V in Prague, his own country was open to attack, which came quickly and surgically in the form of Spinola's troops, who took Oppenheim in 1620. After Frederic's crushing defeat at the Battle of White Mountain and his subsequent garter-less flight to the Hague, Spanish troops besieged, then sacked, Heidelberg in 1622, carrying away with it as booty the famous library, the Biblioteca Palatina. De Caus himself did not follow Frederic and Elizabeth to Prague, but instead left to find service with the French King in Paris, where De Caus died in 1626, after having been made responsible for Paris' public waterworks. What happened to Hero after Europe plunged into (or stumbled through, depending on which version you prefer) the Thirty Years War? Did Hero emerge intact after the Treaty of Westphalia, or was he mortally wounded in the wars that ravaged Europe from 1618-1648? Certainly, Hero's ideas had spread throughout Italy, and north to France, Germany and England by the early years of the 17 th century. As Boas argued, like Vitruvius, Hero rapidly became a reference point and was being cited by natural philosophers such as Francis Bacon, Robert Burton and William Gilbert, ${ }^{71}$ to name only a few. Nevertheless, after Heidelberg, there were no great gardens full of mechanical and hydraulic wonders. Fashions changed, surely, but so did the intellectual framework in which automata were wonders. Uprooted from the rich magical soil of the late Renaissance, the marvels of the Renaissance gardens become again what they had probably been to Hero just toys.

To understand Hero's fate in the 17 th century, I would like to return to the observations I made in my opening remarks: the difference between readers and makers, between a reader's knowledge and a maker's knowledge, between the reception by readers and the reception by makers and finally the difference between readers' memories and makers' memories. Although contemporary science can still be described by anthropologists as a practice dominated by the making and reading of texts, ${ }^{72}$ it is equally clear that the rise of modern science involved a turn away from a world in which texts were central towards a world in which actions and observations could claim to be powerful enough to refute each other. ${ }^{73}$ This pro- 
cess was neither immediate nor continuous, but the victory of the modern science was a victory for the primacy of shared observation over the compelling evidence of texts and textual authority. ${ }^{74}$ The process began in part with challenges to texts from within texts themselves, as signalled by Casaubon's attack on the Corpus Hermeticum, ${ }^{75}$ which demonstrated that rather than being of Mosaic antiquity, the writings of the Egyptian Thoth could be dated - from philological evidence to the first centuries of the Common Era. ${ }^{76} \mathrm{At}$ the same time, the debate over the nature of the vacuum undermined the primacy of Aristotle's physics, just as Copernicus, Kepler and Galileo challenged Ptolemy's astronomy. ${ }^{77}$ This is not the place to document this process in detail, ${ }^{78}$ but it is clear that when Europe emerged from the long decades of struggle with Spain's aspirations to European hegemony. ${ }^{79}$ and England from the turbulent years of Cromwell's universe, in which the royal son Charles I himself lost his position at the centre of the body politic - and his head - the world was a very different place. ${ }^{80}$ The world of Boyle and the Royal Society was not seen by its key actors through the same lens as the world of Drebbel, Fludd or Hobbes. ${ }^{81}$ This shift from texts to observation, from readers to makers - has far-ranging consequences for the ways in which memories are preserved.

Much has been written in recent decades trying to undermine Yates' argument for the centrality of Christian Hermeticism as the key to understanding the late Renaissance. However, when it comes to the renewed and sustained interest in automata - particularly Heronic pneumatic automata - I can do no more than concur with Anthony Grafton:

Modern historians of the automaton - like Simon
Schaffer and Gaby Wood, authors of two excellent, complementary accounts - usually connect the rise of automata with the rise of a new, mechanistic philosophy (as well as with new political and military conditions, like the creation of a well-ordered police state and the military revolution). These correlations are genuine; but they are also partial, a result of taking the seventeenth century's rhetoric of novelty and innovation too literally. In fact, as I have tried to show, both the automaton and the cluster of devices related to it and the mechanised understanding of the body that underpinned them grew up in a very different world - as only one constellation in a vast starry cosmos of theories and practices, which gradually came to outshine and dominate the rest. The great historian Frances Yates argued long ago that learned magic, with its promise of power over the world, was one part of the soil from which the New Science of the late sixteenth and seventeenth centuries grew. Many have corrected her, on points of detail too numerous to mention here. Yet on the main point, as so often, her instincts were sound. The particular delta where the two rivers of magic and technical practices came together in the fifteenth and sixteenth centuries turned into spectacularly fertile intellectual territory and the grafting of magic and engineering that took place around 1500 produced spectacular orchards, which in turn yielded remarkable new fruits. ${ }^{82}$

To understand why Hero was remembered, however, we must recognise that the process was discontinuous, and cannot be described as simply an easy stroll from the dark woods of magic and superstition to the sunny gardens of modern science. Hero survived because for the readers of Hero, his works spoke to a world in which statues moved according to celestial influences. He was remembered - at least in part - because the receivers of his works and the visitors to the animated gardens still inhabited a world of texts, in which texts had 
real power - and magical power to boot. ${ }^{83}$ But it was the makers who would have the last word. As the magical world crumbled, dissolved, shred or was driven underground, ${ }^{84}$ the gardens remained, and their makers of statues had every reason to believe were driven by bellows and boilers, not super-celestial beings. Even before Drebbel's alchemy became the chymistry of Boyle and Starkey ${ }^{85}$ - themselves still alchemists just as Kepler remained an astrologer - the 'rude mechanicals' had already confronted the disparity between the magical texts and their very real machines. ${ }^{86}$ Even though it would be many decades before the makers would be welcome at the table of the Royal Society, their performative knowledge was shaping the discourse about the nature of the world. ${ }^{87}$

Maker's knowledge is situated knowledge it consists of a series of practices aimed at a practical result - the object. The maker's knowledge, and indeed her memories, is in effect 'dissolved' in the object, which once made, is mute. This is in effect at the heart of the museum professional's dilemma. Texts can still be used to capture memory - both texts that record what was claimed ${ }^{88}$ and the absence of texts that declare what was suppressed ${ }^{89}-$ but objects 'incorporate' their memories, and in a very real sense the object serves only as a potential prompt or prop for the eventual 'reperformance of a situated, incorporated memory. ${ }^{90}$ So it is with Hero. As a writer, he was hardly a towering figure. Nevertheless, his writings were recovered as texts in an age in which texts were the key to building the present. However, once claimed by makers such as engineers and architects, the texts became both unnecessary and in some ways irrelevant, and they passed from sight - the first Greek edition of Hero was only published in $1693 .{ }^{91}$
Instead, the memory of Hero - of his greased belts and leather pulleys, his wooden gears and his copper kettles - survived in his gardens. Unfortunately, gardens are fragile and ephemeral, and as objects are far less resilient than parchment, paper or stone.

\section{CONCLUSION}

What does this mean for today? How does understanding the transmission of Hero's dragon-slaying automata affect how we look at contemporary memory? I would like to conclude with an example drawn directly from my recent museum experience at the Museum for Applied Art in Frankfurt, where I was Director General from 1999 to 2003. At the museum (then known by its abbreviation, mak.frankfurt), we tried to confront the challenges of conserving a trace of the culture that was being created by digital media - but which often has no corresponding object (a web page for instance) or when it does, the object itself is uninformative (such as a computer or a computer disk).

In June 1999, the museum launched a project entitled 'Digital Craft', a three-year research project in collaboration with Frankfurt's Institut für neue medien (INM), that had as its goal to define a museum approach to what can only be described as the applied arts of the next century - digital media. The Digital Craft project had two distinct parts: 'using digital craft' as a means of supporting users of the museum (internal and external), and 'defining digital craft', a research project to provide the theoretical basis for a museum strategy, culminating in a collection, public exhibitions, a curator and plans for further research. The first part, 'Using Digital Craft', was a prerequisite of the second, as it created the op- 
portunity to conduct research with visitors in the museum. In its first two years, the Digital Craft team had created the world's first exhibition of computer viruses ${ }^{92}$ and of file sharing. ${ }^{33}$

The applied arts of the 20th and 21st centuries are not limited to physical artefacts, whether one-offs or designed. As McCullough states, 'Ultimately the computer is a means for combining the skilful hand with the reasoning mind'. ${ }^{94}$ The products of mind and hand can be virtual as well as material, and mak.frankfurt's interest in the applied arts stretches from the distant past into the virtual world of the future. Digital artefacts increasingly shape the world around us. Digital products are legitimate, even indispensable objects for our museum collections. Certainly there are museums that already collect hardware - computer museums, film museums, museums of the moving image, technology museums - and there are museums that collect digitally created art, such as the ZKM (Zentrum für Kunst und Medien) in Karlsruhe and the Ars Electronica Zentrum in Linz. But who is collecting the computer games, the websites, the Palm Pilots, the mobile phones - all artefacts whose interest lies in their combination of beauty and utility? Many museums use digital media - but who is collecting it?

The answer is that despite the huge number of projects in this field worldwide, only a few museums have taken this challenge seriously. For example, in the early years of the 21 st century, the San Francisco MoMA collects websites as part of its graphics department - almost as an afterthought - and the ZKM has a handful of early computer games, almost by chance. But what makes a website interesting is not necessarily its graphic design, but its connectivity. How do we collect and store connectivity? What makes DOOM an inter- esting game is not anything that can be captured on a hard disk - in fact, it is not that interesting in purely gaming terms. What makes DOOM or MYST interesting is that they are the first multi-player networked games to be played over the Internet. Even in the case of stand-alone computer games, what is of interest as cultural historians and as museum professionals? Surely the games themselves have value as artefacts, but if we reflect even a little on the differences between the first PONG players and the current generation of computer-fluent game players, might it not also be of interest to collect - somehow - how the games are played? How do we collect such artefacts? How do we conserve them? How do we research them? How do we exhibit them? These are non-trivial questions if we are to preserve our cultural heritage for future generations, which is to say, if we are to fulfil our mission as museums. What will a historian have to refer to a century from now when she comes to write the cultural history of the late 20th century? We contacted many game manufacturers, and few of them bothered to keep early prototypes.Nintendo certainly does not. In many firms, it is the employees that preserve the legacy of the past - not the company itself. In fact, the richest source for early games is now to be found on the Internet itself - via eBay.

If museums are unable to face the challenge of collecting the new applied arts, we run the risk of facing a 'black hole' in cultural history in thirty years time. Trying to describe the explosion of Internet use, or the breathtaking speed at which mobile phones have conquered the market, what will the historian have as material evidence? Who will have saved the first website? Who will have a record of the development of WAP protocols to accompany 
the Nokia 7110 ? In a world in which the oldest Internet company on the planet is only seventeen years old, who is preserving the traces of our culture as we hurtle headlong into the future?

As we have seen, the nature of technology has a powerful influence on which memories are preserved, and which memories are lost. Hero successfully made the leap from papyrus rolls to parchment codices, and managed to be copied and thus survive - albeit in few manuscripts - even after the capsizing of the Ark that was Constantinople. Hero survived into the Renaissance, to be re-translated by architects and engineers into gardens, and to be largely forgotten by natural philosophers. In the case of Hero, the medium in which his ideas were preserved altered both the nature of perception and the perception of nature. In the gardens of Buontalenti, the Francini and De Caus, Hero could be found in the objects themselves - either in the form of direct quotations, or to the extent in which his ingenious toys found new uses in the Renaissance court. Regrettably, situated knowledge is unstable and ephemeral, and unless re-translated once more into texts, passes out of memory with the passing of the makers. Mechanisms no longer explain the questions to which they were once clearly the answers, and remain at best mute witnesses enshrined in our museums, their dissolved meanings latent, waiting for future generations to tease out. We are now confronted with a new generation of objects - objects that have no substance at all whose existence will prove to be far less robust than papyrus, parchment or paper.

It is to this challenge that those of us in the memory business - especially the museum world - will have to address ourselves if we are not to be condemned to living in a perpetual present in which the past evaporates as soon as

it is created. But our challenge is not only a technological one. It is also a matter of values, a matter of choosing which memories are to be preserved - as well as how. If the difficult and contingent history of the transmissions of Hero's ideas into the Renaissance teaches us anything, it is that museums have to look at their role in a new light, and see their role as one of preserving the myriad voices - often contradictory - of makers and of readers alike, rather than trying to present a single, coherent closed narrative. Museums should adopt a strategy of 'visible listening' and make it their goal not only to preserve the material traces of human culture, but the voices of those who left behind those traces. The museum must move beyond the object to the voice, and begin to preserve not only the objects themselves, but also the maker's knowledge situated in the making of objects - perhaps paradoxically by capturing it again as text. Through interviews and videos, the museum can become a repository not only of things but also of memories and skills. In a sense, this means that museums must see themselves as instruments of collective memory, not only of analytic history.

Bob Archibald of the Missouri Historical Society argues that 'Museums are the perfect place to experience empathy, to look at the world through the eyes of others who lived in different places, at different times, and in different circumstances. Objects and images are our business. Every one of them is a potential mnemonic device, a touchstone for memory, an opportunity for important discussion. Museums exist for people, living, dead, and unborn. These institutions are places where the boundaries between past, present, and future are permeable and the interconnections appa- 
92 rent. Museums are never passive although some people struggle to make them so'. ${ }^{95}$ If we are to avoid a Hero's fate of being entombed in motionless statues staring blindly, we must relinquish our hold on the choice of which voices to enshrine in our museum's curatorial texts, and begin to admit other voices, new voices, dissenting voices into the sacred space of the museum. Only then can we keep faith with the future generations who have charged us with the mission of collecting, preserving, studying, interpreting and exhibiting our shared heritage. ${ }^{96}$

\section{November 2007}

\section{NOTER}

1. One of the best overviews of ancient mechanics can be found in A.G. Drachmann, The Mechanical Technology of Greek and Roman Antiquity, p. 12, 19, Munksgaard; Copenhagen: 1963.

2. Bennet Woodcroft, The Pneumatics of Hero of Alexandria (facsimile), introduction by Marie Boas, pp X-XI, Elsevier; London: 1971.

3. Boas, op.cit pp XII-XIII.

4. Hill, Donald, in Learning, Language and Invention: Essays presented to Francis Maddison, pp. 188-206, Variorum; Aldershot: 1994.

5. Boas, Marie, Hero's Pneumatica: a study of its transmission and influence, Isis, Vol. 40, No. 1 (Feb. 1949), p. 39.

6. Netz, Reviel and Noel, William, The Archimedes Codex, p.76, Weidenfeld \& Nicholson; London: 2007.

7. Sezgin, Fuat, Geschichte des Arabischen Schriftums, Band V, Mathematik bis ca. $430 \mathrm{H}$. pp.152-154, Brill; Leiden: 1974.

8. Boas op.cit. p. 40.

9. Jonathan Harris, Byzantines in Renaissance Italy, Hellenic Institute, Royal Holloway, University of
London, 2006 online http://www.theorb.net/encyclop/late/laterbyz/harris-ren.html.

10. Op.cit.

11. Op.cit.

12. Labowsky, Lotte, Bessarion's Library and the Biblioteca Marciana, pp. 148-189, Sussidi Eruditi; Rome: 1979.

13. Boas, op. cit p. 40.

14. Heronis Alexandrini Spiritalium Liber. Ex Graeco, nuper in Latimum Conversus. Federico Commandino Urbinate, Urbino: Cum Privilegio Gregorii XIII. Pont. Max, 1575.

15. Labowsky op.cit.

16. Moranti, Maria and Luigi, Il Trasferimento dei 'Codices Urbinates' alla Biblioteca Vaticana, Accademia Raffaello; Urbino: 1981.

17. See Guasti, C. Giornale Storico degli Archivi Toscani, Vol VI/VII, Gabinetto GP Vieusseux; Florence: 1862/63 for the first inventory of the library at Urbino.

18. Spiritalium liber, à Federico Commandino ... ex Graeco in Latinum conversus. Huic editioni accesserunt Jo. Bapt. Aleotti Quatuor Theoremata Spiritalia, ex Italico in Latinum conversa.Amsterdam, Janssonius van Waesberge, 1680.

19. Hill cites A.J. Turner as saying in The Time Museum (1984) that over 100 manuscript copies of Hero's Pneumatics and Automata were extant in the 16th century. op. cit. Hill.

20. Gli artificiosi et curiosi moti spirituali di Herone tradooti da M. Gio. Battista Aleotti d'Argenta, per Vittorio Baldini; Ferrara: 1589.

21. De gli Automati, overo Machine se Moventi, libri due, tradotti dal Greco da Bernardino Baldi, Venice: Girolamo Porro; 1589.

22. Spiritali ridotti in lingua volgare da Alessandro Giorgi da Urbino Urbino Ragusii 1592.

23. See Eamon, William, Science and the Secrets of Nature, Princeton University Press; Princeton: 1994.

24. Paris: 1588. 
25. Published by his grandson Ottavio at Paul Iacques, Francfort sur le Main: 1617.

26. Lyon: 1578.

27. Revised and updated version published by Wechel; Frankfurt: 1591.

28. Forone of the best and most thorough discussions of Renaissance automata, see Marr, Alexander, Understanding Automata in the Late Renaissance, Journal de la Renaissance, Vol. II (2004), CESR/Brepols.

29. See Marsilio Ficino e il ritorno di Ermete Trismegisto, ed. Carlos Gilly et al. Florence; Centro Di: 1999 and Magia, Alchimia, Scienza dal ‘ 400 al '700, ed. Carlos Gilly and Cis van Heertum, Florence; Centro Di: 2002.

30. For an extensive discussion of Agrippa and the use of talismans in the Renaissance, see Pierre Béhar, Les langues occultes de la Renaisance, Paris; Editions Desjonquères: 1996.

31. A whole generation of Renaissance scholars has earned their degrees revising the pioneering historical research of Frances Yates, which despite being wrong in many particulars, still remains uniquely valid in its general argument that the rediscovery of the Hermetic texts had a profound influence on Renaissance philosophy. See Frances Yates, in particular Giordano Bruno and the Hermetic Tradition, University of Chicago; Chicago: 1964.

32. Augustine's condemnation of the Asclepius is well documented, but for an in-depth analysis of the arguments used in defence of natural magic see Grafton, Anthony, A Note from onside the Teapot, Cornell University lecture, 1997.

33. Op.cit. Yates p. 37.

34. Giorgi, op.cit.

35. Rossi, P, Clavis Universalis, Riccardo Ricciardi; Bologna: 1960.

36. In a well-known account, John Dee was almost arrested for having contrived a piece of self-moving stage machinery for Aristophanes in 1547, see Marr op. cit.

37. Examples abound of serious practitioners believing in the efficacy of talismans and other practices, see Eamon, op.cit or the long debate about the efficacy of the Paracelsan weapon salve.

38. Curtis, Joseph, The water organ and other sound-producing automata, unpublished paper; 2000.

39. See Yates, The French Academies of the Sixteenth Century, Warburg Institute; London: 1947.

40. Dillon Ford, Joseph, From Vocal Memnon To The Stereophonic Garden: A Short History Of Sound And Technology In Landscape Design, CELA, Miami: 1995.

41. Montaigne, Michel, Travel Journal 1580-81 Transl. Donald M. Frame. San Francisco: North Point Press, 1983. cf. http://catena.bgc.bard.edu/texts/montaigne.htm

42. Theorem XV.

43. Vieri, Francesco de', called Il Verino Secondo. Discorsi di F. de' V. delle maravigliose opere di Pratolino e d'Amore Manescotti; Firenze: 1586

44. Evelyn, Works, 1955, vol. 2, pp. 418-19.

45. Fynes Moryson, An Itenerary written by Fynes Moryson, Gent. First in the Latine Tongue, and then translated by him into English. (Containing his ten yeeres travell through the twelve dominions of Germany, Bohmerland, Sweitzerland, Netherland, Denmarke, Poland, Italy, Turky, France, England, Scotland, and Ireland.). J. Beale: London: 1617.

46. Sgrilli, Bernardo Sansone, Descrizione della regia villa, fontane e fabbriche di Pratolino Firenze: 1742.

47. op.cit Vieri p.57 Cap. III Comparatione di alcune artifitiossime opere di Prataolino con alcune de gli antichi.

48. Gualterotti, Rafaello, Feste nelle Noce del Serenissimo Francesco Medici, Giunti; Firenze: 1579.

49. See Dezzi Bardeschi, Marco et al. in Pratolino Laboratorio di meraviglie (particularly Volume 1, 
La Fonte delle fonte), Provincia di Firenze/Alinea; Florence: 1986.

50. Erone, Del vuoto, tradotto di Bernardo Davanzati, degli sezione iniziali degli Spiriituali di Erone, Versione dedicata anche questa a Buontalenti, Firenze: 1582.

51. Hero Alexandrinus, Libro degli artifizii spiritali over di fiato, 1582. The Libro degli artifizii spiritali over di fiato is the first Italian translation of Hero's Pneumatics. It was produced by Oreste Vannoccio Biringuccio at the request of Bernardo Buontalenti, chief engineer of the Tuscan Grand Duke Francesco I. He also translated into Italian Piccolomini's paraphrase of Aristotle's $\mathrm{Me}$ chanical Questions in the same year. Oreste Vannoccio Biringuccio was the nephew of Vannoccio Biringuccio, who was famous for his De la pirotechnia (1540). The translation was produced mainly on the basis of the Latin editio princeps of Commandino, published in 1575. However, the author may also used a Greek manuscript of Hero's Pneumatica, at that time preserved at the Vatican - presumably a copy of the manuscript Bessarion had brought with him to Rome in 1461, prior to confiding it to Urbino in 1472.

52. Theorem XL.

53. Op.cit. vol. 2, 111.

54. See Saintenoy,Paul, Les arts et les artistes à la cour de Bruxelles, Brussels:1932,33,35.

55. See Strong, R. The Renaissance Garden in England, Thames \& Hudson, London: 1979 especially Chapter IV.

56. De Caus, S. La perspective avec la raison des ombres et mirroirs, Jan Norton, London: 1612.

57. Strong op. cit. pp. 141-158 and 216-217.

58. Shirley J.W. The Scientific Experiments of Sir Walter Raleigh, the Wizard Earl, and the Three 'Magi' in the Tower. Ambix 4, 1949 nos 1\&2, pp. 52-66.

59. For a complete analysis of Drebbel and the perpetuum mobile see Bradburne, J. Going through the motions, unpublished paper, London: 2006

60. See Strong, R. Henry, Prince of Wales and England's Lost Renaissance, Thames \& Hudson, London: 1986 especially pp. 86-138.

61. Strong, R. op.cit.

62. Prince Henry had himself been seen as the inheritor of the legacy of Henry IV, assassinated in 1610 see Strong op.cit.

63. Much criticised, the context in which Frederic V and Elizabeth Stuart became the 'Winter King and Queen' of Bohemia is explored in Yates, Frances, The Rosicrucian Enlightenment, Routledge; London: 1972.

64. The British historian, Sir Hugh Trevor-Roper, maintained that to write history well, one had to look at the ways in which decisions were made from the standpoint of the times in which they were made, without the benefit of knowing the outcome in advance.

65. De Caus nevertheless left a substantial English legacy, and his Les raisons was later revisited by his younger brother Isaac, who published an edited version entitled Nouvelle invention de lever l'eau plus hault que sa source avec quelques machines mouvantes par le moyen de l'eau et un discours de la conduite d'icele (London, 1644) in which he was less reticent about making claims for a perpetual motion in Problem IX. An English edition was subsequently printed in 1659 by Joseph Moxon, friend of Robert Hooke and printer for the Royal Society. The English edition is entitled: New and rare inventions of water-works shewing the easiest waies to raise water higher then the spring : by which invention the perpetual motion is proposed: many hard labours performed: and varieties of notions and sounds produced: a work both usefull profitable and delightfull for all sorts of people.

66. Patterson, Richard, The Hortus Palatinus and the Reformation of the World. Part I: The Iconography of the Garden, Journal of Garden History 
1, no. 1 (1981): pp. 67-104 and Patterson, Richard, The Hortus Palatinus and the Reformation of the World. Part II: Culture as Science, Journal of Garden History 1, no. 2 (1981): pp. 179-202.

67. Morgan, Luke, Nature as Model, University of Pennsylvania; Philadelphia: 2007.

68. Morgan op.cit pp. 148-150.

69. See Strong, Roy, The Renaissance Garden in England, Thames \& Hudson; London: 1979.

70. See Shakespeare, W. The Tempest, ed. Stephen Orgel, OUP; Oxford: 1987.

71. Boas, op. cit. p. 42.

72. Latour, B. and Woolgar, S. Laboratory Life; the construction of scientific facts, Sage; New York: 1979.

73. For an excellent account of this transformation see Sutton, G. Science for a Polite Society, Westview; Boulder: 1995.

74. See Newman, W. Gehennical Fire: the lives of George Starkey; University of Chicago: 1994 and Principe, L. The Aspiring Adept: Robert Boyle and his alchemical quest; Princeton: 1998.

75. De rebus sacris et ecclesiaticis, Norton; London: 1614.

76. Op.cit Yates, F. The Rosicrucian Enlightenment.

77. For a rather free-wheeling and particular account, see Koestler, A. The Sleepwalkers, Hutchinson; London: 1959.

78. For a more detailed analysis of this transformation, see Newman, W. and Grafton, A. Eds. Secrets of Nature, MIT; Cambridge: 2001.

79. See Trevor-Roper, H, The Outbreak of the Thirty Years War and The Paracelsan Movement in Renaissance Essays, University of Chicago: 1985.

80. See Hill, C. The World Turned Upside Down: radical ideas during the English Revolution, Maurice Temple Smith; London: 1972.

81. The classic account of the confrontation between pre-Thirty Years War natural philosophy and nascent modern science can be found in Shapin,
S. and Schaffer, S. Leviathan and the Air pump:

Hobbes, Boyle and the experimental life, Princeton: 1985.

82. Grafton, Anthony, Magic and Technology in Early Modern Europe, Dibner Library Lecture, Smithsonian Institution; Washington: 2002.

83. See Newman, W. Promethean Ambitions: alchemy and the quest to perfect nature; University of Chicago: 2004.

84. See Dickson, D. The Tessera of Antilia, Brill; Leiden: 1998.

85. Newman, W. and Principe, L. Alchemy Tried in the Fire: Starkey, Boyle and the fate of Helmontian Chymistry, University of Chicago: 2002.

86. See Shapin, S. A Social History of Truth: civility and science in seventeenth century England, University of Chicago: 1994.

87. Op.cit. Shapin.

88. An authoritative demonstration of the use of textual evidence to reconstruct the significance of a Renaissance garden can be found in Breekamp, H. Vicino Orsini e il Sacro Bosco di Bomarzo, Werner'sche Verlag; Worms: 1985, in Italian l'Elefante; 1989.

89. See Hedrick, C.W. History and Silence, University of Texas; Austin: 2000.

90. For an extended discussion of the importance of situated knowledge in the Renaissance, see Smith, P. The Body of the Artisan; University of Chicago: 2004 and Moran, B. Distilling Knowledge: alchemy, chemistry and the scientific revolution, Harvard University; Cambridge: 2005.

91. Despite the number of Latin and vernacular translations that flourished in the late 16th century, there was no Greek edition of Hero's works until 1693, in Thévenot's Veterum Mathematicorum opera and even that was corrupt.

92. Nori, F. ed. i love you, mak.frankfurt: 2002.

93. Nori, F. ed.aDonnaM, mak.frankfurt: 2003.

94. McCullough, M. Abstracting Craft: the practised digital hand, p. 14, MIT; Cambridge: 1997. 
JAMES M. BRADBURNE

96 95. Archibald, R. R. Touching on the Past, unpublished paper, Missouri Historical Society; St. Louis, Missouri: December 2006.

96. In 1970, in an address to the American Association of Museums of which he was then President, Joseph Veach Noble defined the mission of a museum in terms of five museum 'fingers' which together worked in concert as the museum 'hand'.

* Dr. James M. Bradburne AADipl MCSD

Director General

Address: Fondazione Palazzo Strozzi

Piazza Strozzi, 50123 Firenze ITALIA

Phone:+39055 2776461

E-mail: j.bradburne@fondazionepalazzostroz-

zi.it

www.bradburne.org 